

\section{Hjemmesykepleien i samhandling med spesialisthelsetjenesten}

Forfattere: Siri Tønnessen, Bente Lilljan Lind Kassah og Wivi-Ann Tingvoll

\section{NøKKELORD}

- Hjemmesykepleie

- Kvalitativ studie

- Makt

- Samhandling

- Spesialisthelsetjeneste

\section{INTRODUKSJON}

Ifølge Stortingsmelding 47 Samhandlingsreformen (heretter kalt reformen) er bedre samhandling et av helse- og omsorgstjenestens viktigste utviklingsområder. Samhandling fremheves som sentralt for å sikre målet om en sammenhengende og helhetlig tjeneste til pasientene (1). I reformen beskrives samhandlingen mellom spesialist- og kommunehelsetjenesten som særlig utfordrende. Studier viser blant annet at oppfølgingen av pasienter i overgangen fra sykehus til hjemmesykepleie har vist seg å være spesielt vanskelig (2-9). For å bidra til et mer helhetlig pasientforløp har man i mange kommuner innført ulike former av bestiller-utførermodellen (BUM). Studier viser imidlertid at samarbeidet mellom helsepersonell er usystematisk og mangelfullt når det gjelder vurderingen av pasienters funk- sjonsnivå og hjelpebehov, samt at dokumentasjonen som folger med pasientene ikke er tilfredsstillende (3-8). Reformtiltakene innført i januar 2012 har derfor som mål at samhandlingen mellom aktørene skal bli bedre. I denne artikkelen presenterer vi en studie av hvordan sykepleiere i hjemmesykepleien opplever sambandlingen med helsepersonell i spesialisthelsetjenesten to og et halvt år etter innføringen av reformen. Vi belyser samhandlingen mellom aktørene ved å fokusere på utfordringer som oppstår når pasienter skrives ut fra sykehus og overføres til hjemmesykepleien. Hensikten med artikkelen er å utvikle kunnskap om hvilke utfordringer som oppstår i samhandlingen, og hvordan utfordringene håndteres.

\section{BAKGRUNN}

Samhandling er «helse- og omsorgstjenestens evne til oppgavefordeling seg imellom for å nå et felles, omforent mål, samt evnen til å gjennomføre oppgavene på en koordinert og rasjonell måte» (1 s. 13). Ifølge Orvik (10) er samhandling forpliktende og inneholder et juridisk og etisk imperativ om at aktørene skal handle sammen i konkrete situasjoner slik at pasienter og pårø- rende opplever sammenheng $\mathrm{i}$ tjenester og tiltak. Samhandling fordrer derfor gjensidig tilpasing av partenes arbeidsoppgaver, felles forståelse av situasjonen og av at samhandling er nødvendig. Samarbeid og samordning er sentrale elementer $i$ samhandling $(2,10)$. Samarbeid beskrives som en positiv innstilling mellom aktører som fører til uformell kontakt uten at det nødvendigvis er en sterk grad av forpliktelse til konkrete handlinger (10). Samordning handler om å formalisere tiltak, enten innenfor den enkelte organisasjon eller mellom organisasjoner, for å løse bestemte oppgaver og realisere felles mål. Samordning krever beslutninger på systemnivå (10).

\section{Hva tilfører studien?}

Hjemmesykepleierne i denne studien opplever at samhandlingen begrenses av organisatorisk skjevfordeling av makt.

\section{Mer om forfatterne:}

Siri Tønnessen er sykepleier med PhD i medisinsk etikk og $f \varnothing r-$ steamanuensis ved Høgskolen i Sørøst-Norge, campus Vestfold. Bente Lilljan Lind Kassah er førsteamanuensis og Wivi-Ann Tingvoll førstelektor, begge ved UiT, Norges arktiske universitet. Kontaktperson: siri.tonnessend 
I Stortingsmelding 47 (1) tilskrives utfordringene i samhandlingen mellom spesialisthelsetjenesten og kommunene, blant annet at helseforetak og kommuner er forankret i forskjellig lovverk og at de har ulike betalingsordninger og insentiver. Videre er målet for spesialisthelsetjenesten medisinsk helbredelse, mens kommunehelsetjenesten vektlegger pasientens funksjonsnivå og mestringsevne. I stortingsmeldingen beskrives det også kommunene må betjene har økt, samtidig med at pasientene som skrives ut er sykere enn før (1321). Kommunenes nye ansvar handler derfor i stor grad om behandlingsrelaterte oppgaver og ivaretakelse av pasienter i en svært sårbar fase $(13,16,17,20)$. Dette innebærer et økt press på kommunale tjenester og hjemmesykepleien spesielt, særlig i de kommunene som har for få korttidsplasser $(16,18)$. Organiseringen i en bestiller-utførermodell ser også ut til å begrense

\section{Det storste grepet i reformen har vært å overfore oppgaver og ansvar fra spesialist- helsetjenesten til kommunene.}

som et samhandlingsproblem at utskrivningsklare pasienter beslaglegger et betydelig antall liggedøgn i sykehusene. Reformen har derfor hatt som mål å iverksette systemtiltak som understøtter samhandling når pasientens behov for tjenester går på tvers av forvaltningsnivåer eller organisatoriske grenser. Det største grepet i reformen har vært å overføre oppgaver og ansvar fra spesialisthelsetjenesten til kommunene. Tiltak som er igangsatt for å imøtekomme forskyvningen av oppgaver og ansvar til kommunene er blant annet: Krav om «samhandlingsavtaler» mellom partene, kommunal betaling for liggedøgn i sykehus for pasienter som er definert som utskrivningsklare og opprettelse av stillinger som samhandlingskoordinatorer i helseforetakene $(1,11,12)$.

Samhandlingstatistikk 2013-2014 viser at insentivet om kommunal betaling har bidratt til å redusere antall liggedøgn på sykehuset for utskrivningsklare pasienter betydelig $(13,14)$. Antallet pasienter mulighetene for å ivareta eldre pasienters pleie- og omsorgsbehov (15). Flere uttrykker bekymring for om den kommunale tjenesteoppfølgingen av pasientene er tilfredsstillende $(13,16,17,19,20)$. Det er også uklart om samhandlingen mellom sykehus og kommuner om den enkelte pasient er blitt bedre etter innføringen av reformtiltakene $(13,19,20)$.

\section{METODE OG MATERIALE}

I tråd med studiens hensikt valgte vi et kvalitativt design $(22,23)$. Snøballmetoden ble benyttet for å få tilgang til informanter som hadde samhandlingserfaring med aktører i spesialisthelsetjenesten. Gjennom sosiale nettverk fikk vi opplysninger om mulige informanter som vi tok kontakt med. Disse informantene sendte oss videre til andre sykepleiere i hjemmesykepleien som også samhandler med spesialisthelsetjenesten. $\mathrm{Vi}$ benyttet semistrukturerte dybdeintervjuer som datainnsamlingsmetode $(22,23)$. Sju sykepleiere fordelt på en land- kommune og en bykommune innenfor samme helseforetaksområde ble intervjuet. Fire av sykepleierne arbeidet med å yte tjenester direkte til pasientene. Tre av sykepleierne var administrative ledere med ansvar for å planlegge tjenesteytingen og ta imot pasienter fra sykehuset. Vi valgte å intervjue sykepleiere med både klinisk og administrativt ansvar. Vi antok at med ulikt ansvar i hjemmesykepleien kunne de ha forskjellige erfaringer i samhandlingen med spesialisthelsetjenesten. I intervjuene ble det vektlagt å få fram sykepleiernes beskrivelser av hvordan samhandlingen med sykehuset om pasienter som skrives ut til hjemmesykepleien fungerer etter innføringen av reformen. For å sikre dataenes kvalitet reformulerte vi ofte informantenes utsagn i form av spørsmål. Dette for å være sikker på at vi forsto det informantene ønsket å formidle (23). Intervjuene ble gjennomført sommeren 2014 av to forskere, og varte fra en til halvannen time. Intervjuene ble tatt opp på bånd og transkribert.

\section{ANALYSE}

Data er analysert og fortolket ved hjelp av fenomenologisk hermeneutisk tilnærming (23). $\mathrm{Vi}$ foretok meningsfortetting og utvikling av meningsenheter, noe som ikke var en linjær prosess, men en fortolkende vandring mellom rådata, mulige subtemaer og temaer. Først ble sitater som omhandlet utfordringer i samhandlingen markert og mulige subtemaer notert i margen. Deretter ble det laget oppsummeringer av det enkelte intervju, der sitater ble samlet i subtemaer og samtidig ble mulige temaer utviklet. Videre ble subtemaer og temaer fra alle oppsummerin- 
gene sett på tvers. Det innebar å analysere fram felles subtemaer og temaer samtidig som overflødig materiale ble fjernet. Det ble tidlig klart at samhandlingen om pasienter med kreft var et tema som skilte seg ut fordi samhandlingen fungerte bra. Samhandlingen om andre pasienter som skulle overføres til hjemmesykepleien beskrives drimot som problematisk. Det problematiske handler om at aktørene har ulike perspektiv på hva som skal tillegges vekt i samhandlingen om pasienter. Hjemmesykepleierne beskriver det også som problematisk at de har begrenset makt og innflytelse i samhandlingen og at det er begrenset samhandling og informasjonsflyt mellom aktørene. I tabellen nedenfor illustreres analysen fra subtema til tema.

Etter utformingen av temaene analyserte vi intervjuene igjen for i størst mulig grad å ivareta undersøkelsens validitet (23). I analysen av intervjuene viste det seg at sykepleiernes erfaringer i samhandlingen med aktører i spesialisthelsetjenesten var tilnærmet sammenfallende. Vi skiller derfor ikke mellom informanter med administrative og kliniske oppgaver i datapresentasjonen og diskusjonen.

\section{ETISKE OVERVEIELSER}

Det ble sendt informasjonsskriv og forespørsel om å delta i prosjektet til ledelsen i hjemmesykepleien $\mathrm{i}$ to kommuner som rekrutterte informanter. Det ble innhentet skriftlig informert samtykke og informantene fikk beskjed om at de når som helst kunne trekke seg fra undersøkelsen, noe ingen gjorde. Studien er godkjent av Norsk samfunnsvitenskapelig datatjeneste. Personidentifiserbare opplysninger er anonymisert i transkriberingen.

\section{Tabell 1}

\section{Subtema}

God informasjonsflyt. Kjennskap og forståelse for hverandres arbeidssituasjon.

Vektlegger ulike sider ved pasientens behov og situasjon. Spesialisthelsetjenesten fokuserer medisinsk

behandling, og hjemmesykepleien fokuserer mer på pasientens funksjonsnivå. Aktørene hegner om egen arbeidsmengde.

Formell organisasjonsstruktur gir legene definisjonsmakt.

Opplever at de sjeldent blir hørt.

Spesialisthelsetjenesten lover pasienter tjenester på hjemmesyke-

pleiens vegne.

Mangler formell arena for samhandling.

Begrenset samarbeid og tilgang på informasjon.

Data er lagret etter gjeldende retningslinjer.

\section{RESULTATER}

I det følgende presenteres studiens tematiske funn, og subtemaer fremkommer implisitt gjennom informantenes utsagn.

\section{Kreftomsorgen fungerer}

Ifølge sykepleierne fungerer samhandlingen med sykehuset godt når det gjelder kreftpasienter. De beskriver at sykehuset har et faglig sterkt team som det er lett å kontakte og at «de tenker på alt» når pasienten skrives ut og skal følges opp av hjemmesykepleien. En forklarer hvorfor det fungerer: «Det er egentlig alt. Fra bestilling av varer til alt utstyr som er forventet at vi kanskje kan trenge ved medisinering. Når vi har generelle spørsmål som kan oppstå, så er de veldig lette å få tak i og veldig serviceinnstilte. Både for oss og pasientene».

En annen sier: «Samarbeidet er avhengig av at de på sykehuset kjenner kommunen pasienten skal hjem til, og av hvem man

\section{Tema}

Kreftomsorgen fungerer.

Ulike perspektiver på samhandling

Begrenset makt og innflytelse.

Begrenset samhandling og informasjonsflyt. møter (i spesialisthelsetjenesten). Palliasjon har fungert utmerket.» Sykepleierne fremhever her at god informasjonsflyt er helt avgjørende for å kunne gi gode tjenester. Videre gir de uttrykk for at samhandling forutsetter kjennskap til, og forståelse for, hverandres situasjon.

\section{Ulike perspektiver}

Sykepleierne beskriver at samhandlingen med sykehuset om pasienter som ikke har kreft og som skal overføres til hjemmesykepleien er problematisk. Data viser at aktørene har ulike perspektiver på hva det er ved pasientens behov og situasjon som skal tillegges vekt i samhandlingen: «Samhandling går ut fra det systemet man jobber i. At man kanskje ser på samhandling forskjellig alt ettersom hvor man jobber hen [...] Jeg har et perspektiv på at vi jobber opp mot at brukeren bor hjemme. Men hvis det er snakk om en bruker som skal hjem, så er det liksom mer det at de ser brukeren i et sånt medisinsk perspektiv». 
Ifølge informantene har aktørene i spesialisthelsetjenesten et mer medisinsk perspektiv på pasientens behov enn de selv, som har en mer kontekstuell forståelse av pasientens behov. Personell på sykehuset er for eksempel mest opptatt av medisinsk behandling av pasientens sykdom, mens hjemmesykepleierne sier at de fokuserer mer på pasientens funksjonsnivå og hjemmesituasjon. De ulike perspektivene kan gjøre det vanskelig å samhandle, fordi aktørene

\section{Vi må bare ta pasienten imot.}

vektlegger ulike sider ved pasientens behov og situasjon. Ifølge informantene påvirkes innholdet i samhandlingen også av at helsetjenesten har en presset hverdag og at det er en "alles kamp mot alle». Informantene sier at alle verner om seg selv og skyver ansvar over på andre hvis man har mulighet.

Begrenset makt og innflytelse Sykepleierne beskriver at de opplever å ha begrenset makt og innflytelse i samhandlingen. De forteller at det er sykehuslegene som definerer når en pasient skal overføres til kommunen, og for hjemmesykepleien kan dette være problematisk. En informant sier det slik: «Vi opplever i hvert fall at vi ikke har all verdens med makt. Vi får som regel beskjed om at han eller hun kommer hjem - og det her må dere gjøre. Punktum. Enten fra sykehuset eller fra vedtak fra tildelingskontoret som kanskje ikke er helt tilpasset, for å si det sånn ...".

En annen informant sier videre at: «Vi må bare ta pasienten imot». Informantene beskriver her at de må ta imot pasienter uten at hjelpetilbudet er tilpasset pasientens behov. De forteller videre at pasientene blir overført til kommunene når legene på sykehuset har avklart pasientens medisinske tilstand. Pasientene har imidlertid fortsatt behov for behandling, pleie og omsorg fra hjemmesykepleien. Ifølge informantene har dette medført flere arbeidsoppgaver og økte faglige krav til sykepleierne i hjemmesykepleien. Det har også ført til stadige reinnleggelser og at pasienter blir flyttet mer fram og

tilbake nå enn før. Informantene forteller at de har en samhandlingsavtale med sykehuset om at pasienter ikke skal komme hjem mellom kl. 14.00 på fredager og 08.00 på mandager. Ifølge sykepleierne fungerte dette bra i begynnelsen, men nå bryter sykehuset til stadighet avtalen og pasienter overføres til kommunen og kan komme hjem sent fredag kveld og i helgene.

Sykepleierne beskriver også at de sjeldent blir hørt når de søker dialog med sykehuset. De kan for eksempel gi informasjon om hjemmesykepleiens arbeidssituasjon til sykehuset utallige ganger, uten at aktørene på sykehuset tar informasjonen til etterretning. En informant sier det slik: «Vi opplever at vi sloss mot overmakta».

En annen forteller: «Det som ofte går igjen er jo at vi får pasienter hjem, med resept i hånden - uten medisiner. Det nytter liksom ikke hvor mange ganger vi sier at vi har ikke apotek her $\mathrm{i}$ ... og vi har ingen medisiner, vi har ikke så mye utstyr. Vi har jo ikke noe lager med noe. Så det går ofte igjen at vi får de sendt hjem, uten det de trenger».
Sykepleierne forteller videre at det sjeldent blir tatt hensyn til at hjemmesykepleien har behov for tid til planlegging for å kunne ta imot pasienter. Ifølge informantene handler behovet for planlegging blant annet om at hjemmesykepleien verken har utstyr eller medisiner på lager. Bemanningen er knapp på ettermiddager og helger, og at dagene er uforutsigbare. Sykepleierne beskriver også at både leger og sykepleiere på sykehuset kan love pasienter tjenester fra hjemmesykepleien uten å etterspørre om hjemmesykepleien kan innfri dem. En uttrykker det slik: "Så sier legen eller sykepleieren på sykehuset at: 〈Nå skal du ha hjemmesykepleie $\mathrm{x} 4$, for det trenger du. Og de har ingen formening om hvordan hjemmet er tilrettelagt. Hva de har gjort før. Vi har jo sendt innleggelsesrapport, men det er jo en grov kartlegging. Og så får pasienten vite at nå skal du få hjemmesykepleie x 4 og de skal møte deg, også er det ikke reelt.»

Ifølge informantene skaper lovnadene fra sykehuset forventninger hos pasientene som hjemmesykepleien ikke alltid kan imøtekomme. Sykepleierne forteller at de ofte kjenner pasientene og løser slike situasjoner gjennom samtaler der forventninger dempes og pasientene «trygges».

\section{Begrenset samhandling og informasjonsflyt}

Sykepleierne beskriver at det foregår en begrenset samhandling mellom aktørene. Informantene forteller at hjemmesykepleien ikke har faste, formelle arenaer for samhandling med sykehuset, noe de hadde før innføringen av reformen. En sier: «Vi er mye mindre på 
samarbeidsmøter på sykehuset nå [...]. Jeg hører at mange på tildelingskontoret sier at samarbeidsmøtene på sykehuset er bortkastet tid, fordi det kommer ingen dit som kjenner pasientene. [...] Vi har gitt beskjed om at vi vil være med og de har sagt at de skal ta oss med, men det skjer ingen endring».

Hjemmesykepleien har en avtale om at det skal være "samarbeidsråd» med sykehuset to ganger $\mathrm{i}$ året, men i hovedsak foregår informasjonsutvekslingen via tildelingskontoret. Informantene beskriver dette som en ulempe fordi viktige opplysninger blir borte, som for eksempel informasjon om pasientens funksjonsnivå.

De forteller videre at pasienter sendes hjem uten at epikriser og medisinlister følger med, noe som gjør tilpassingen av tjenestetilbudet til pasientene vanskelig. Noen ganger blir papirene sendt til tildelingskontoret, og da får hjemmesykepleien papirene dagen etter at pasienten er kommet hjem. De kan også få uferdige epikriser. En sier: «Hvis vi er heldige å få noe, så er det ikke ferdige epikriser. Jeg har tatt kontakt med sykehuset og satt fingeren på enkelte ting i epikrisen og spurt spesifikt og får bare til svar at det her er en ikke ferdig epikrise - du kan ikke gå ut fra den. Du må vente på den ferdige). Og den kan komme om en uke så det ...».

Sykepleierne sier at det begrensete samarbeidet om pasientopplysninger gjør dem usikre og at de derfor dobbeltsjekker den mangelfulle informasjonen de mottar. Dette fører til mange telefoner, ekstraarbeid og til at de blir stresset. Den største utfordringen er ifølge en sykepleier: «... å finne frem til de rette som sitter på eksperti- sen når jeg trenger det». Sykepleierne beskriver at aktørene på sykehuset er vennlige når de tar kontakt, men ofte møter de en sykepleier som nylig har kommet på vakt og ikke kjenner pasienten. En sykepleier sier at mangelen på medisinlister en gang førte til at hun måtte ta en avgjørelse om medisinering, noe som ikke er hennes ansvar, men legens.

\section{DISKUSJON}

Funnene viser at samhandlingen om pasienter med kreft fungerer godt. Hovedinntrykket er imidlertid at samhandlingen mellom helsepersonell i sykehus og hjemmesykepleien preges av en organisatorisk skjevfordeling av formell makt mellom aktørene. Dataen tyder videre på at det ikke er etablert en felles forståelse av hva det er viktig å samhandle om. Dette kan blant annet henge sammen med at aktørene har begrenset kunn- «å bare ta imot» pasienter som kommer hjem. Vår studie viser, i likhet med andre undersøkelser, at pasienter skrives tidligere ut, er sykere og mer behandlingstrengende enn før $(16,17,19-21$, 26). Ut fra Hernes sitt perspektiv på makt kan tidlig utskrivning av pasienter forstås som at aktørene i spesialisthelsetjenesten realiserer egen organisasjons interesser og reformens intensjoner om at pasienter skal sendes hjem så snart som mulig. Den formelle maktfordelingen i relasjonen mellom aktørene ser imidlertid ut til å begrense samhandlingen. Dette er fordi legene i spesialisthelsetjenesten kan fatte beslutninger som berører hjemmesykepleiens arbeidshverdag, uten at de blir involvert. Det er mulig at formaliserte tiltak som forplikter aktører moralsk og juridisk til å handle sammen til en viss grad kunne ha utjevnet maktforskjellene. Studien viser imidlertid

\section{Vi får pasienter hjem, med resept i hånden - uten medisiner.}

skap om hverandres arbeidssituasjon.

Aktørenes formelle makt er nedfelt i de lover og regler som regulerer samhandlingen om overføring av pasienter fra spesialist- til kommunehelsetjenesten $(1,11)$. Makt kan ifølge Hernes (24) betegnes som aktørers evne til å realisere sine interesser. Her betraktes makt som et relasjonelt begrep (25). Skjevfordelingen av makt i samhandlingen mellom helsepersonell i sykehus og hjemmesykepleie er forankret i formelle organisasjonsstrukturer. Sykehuslegene har formell makt til å definere når pasienter skal overføres til kommunene. Hjemmesykepleien beskriver at de ikke har noe annet valg enn at samarbeidsrådet, som kan betraktes som et formaliserte tiltak for samhandling, i liten grad fungerer etter hensikten.

Samhandlingsutfordringene kommer også til uttrykk når sykepleierne må søke uformell kontakt med aktører i spesialisthelsetjenesten og opplever at de sjeldent blir hørt. Interaksjonen mellom aktørene tyder på at de har et begrenset samarbeid, fordi, ifølge Orvik (10), samarbeid hviler på at aktørene har en positiv innstilling som gir rom for å etablere uformell kontakt. Det å ikke bli hørt kan også føre til at sykepleierne i hjemmesykepleien opplever avmakt (24). Viktige premisser for samhandling som gjensidig ansvar 
og likeverd kan dermed se ut til å være truet (10).

Studien viser videre at aktørene på sykehuset lover mer omfattende tjenester enn hjemmesykepleien kan innfri og at de bryter samhandlingsavtaler. Disse handlingsvalgene kan sees i sammenheng med at informantene beskriver at helsetjenesten preges av en «alles kamp mot alle» og at aktørene først og fremst tenker på egen «drift». Dette innebærer at aktørene i liten grad løser oppgaver

\section{Funnene viser at samhandlingen om pasienter med kreft fungerer godt.}

sammen, og samhandlingens intensjoner om «å sikre flyt i arbeidsprosesser slik at pasienter opplever helhet i tjenester og tiltak» (10, s. 210), ser ut til å være skadelidende. Den formelle maktstrukturen ser i liten grad ut til å fremme samhandling som forplikter aktørene, og det åpnes et rom for ansvarsforskyvning mellom spesialisthelsetjenesten og hjemmesykepleien.

I studien kommer det videre fram at aktørene har ulike perspektiver på samhandling. Ulike perspektiver kan være et uttrykk for at aktørene i liten grad har etablert en felles forståelse av hva samhandling innebærer, samt hva det er viktig å samhandle om. Dette er beskrevet av andre som utfordringer også før innføringen av reformen (1, 3-5). Det at aktørene handler ut fra ulike perspektiver kan forklare informantenes erfaringer med at informasjonen som følger med pasientene ofte er mangelfull. Begrenset informasjonsflyt kan også forstås som et uttrykk for at den formelle organisasjonsstrukturen i liten grad åpner for kunnskaps- utveksling mellom aktørene. Selve arbeidsorganiseringen i helse- og omsorgstjenesten med turnusordninger bidrar også til at det er utfordrende å få kontakt med aktører som besitter relevant pasientinformasjon. Organiseringen av helse- og omsorgstjenesten kan på den måten dempe mulighetene for samarbeid mellom aktørene, og forutsetningene for å etablere samhandling kan dermed svekkes (10). Studien tyder slik på at det fremdeles er en utfordring

å etablere en felles forståelse av samhandlingens betydning og innhold på tvers av profesjonstilhørighet og organisasjonsnivå. Ifølge Orvik, er en felles forståelse av både samhandling og situasjonen nødvendig for å få til en gjensidig tilpasning av arbeidsoppgaver (10).

Sykepleierne beskriver at samhandlingen om pasienter med kreft fungerer godt, blant annet fordi utskrivningsprosessene preges av god informasjonsflyt og dialog mellom aktørene. Dataene tyder også på at aktørene i sykehuset vet at hjemmesykepleien har begrenset medisinsk utstyr og sørger for at det pasienter trenger er tilgjengelig ved utskrivning. Dette kan bety at aktørene har en fellesforståelse av hva de skal samhandle om og hvordan. En mulig forklaring på at aktørene kan ha etablert en fellesforståelse, kan være at kreft er en alvorlig sykdom som aktualiserer eksistensielle spørsmål som også berører involverte aktører. Samtidig viser forskning at kreft er høyt rangert i prestisjehierarkiet over sykdomsdiagnoser
(27). Dette kan ha betydning for oppfølging av pasienter når de skrives ut fra sykehus og dermed også for samhandlingen mellom aktørene.

Denne studien har bidratt til å belyse hvordan sju sykepleiere fra to ulike kommuner beskriver samhandling med aktører i ett sykehus. Funnene er derfor ikke statistisk generaliserbare. Sykepleierne legger vekt på at samhandling om pasienter med kreft fungerer, mens samhandling om pasienter med andre sykdommer er utfordrende. De opplever at samhandlingen begrenses av en formell skjevfordeling av makt og av at involverte aktører ser ut til å ha ulik forståelse av hva samhandling innebærer og hva de skal samhandle om.

\section{KONKLUSJON}

Studien tyder på at det er behov for både inter- og intraorganisatoriske endringer for å bedre samhandlingen. Et viktig tiltak kan være å etablere en felles samhandlingsarena mellom aktørene, noe som vil være i tråd med Stortingsmelding nr. 26 (2014-2015) (28). Dette vil trolig kunne fremme både kunnskapsutveksling og bidra til økt forståelse for hverandres arbeidssituasjon i samhandlingen om hvordan man ivaretar den enkelte pasient innenfor rammene som er gitt. Organisatoriske endringer kan antakeligvis ikke løse samhandlingsutfordringene alene $(2,28)$. Aktørene må ha både vilje og evne til å samarbeide slik at samhandling er mulig $(10,28)$. Kunnskap, vilje og evne ser ut til å prege samhandlingen om pasienter med kreft. Det å undersøke samhandling som fungerer vil kunne gi verdifull kunnskap som kan benyttes til å forbedre samhandlingen innenfor områ- 
der der den ikke fungerer. Det er også behov for videre forskning som kan klargjøre hva det er aktørene skal samhandle om, hvordan skape vilje til samhandling og hvordan balansere maktrelasjoner mellom aktører. For å kunne belyse de oven- nevnte forskningstemaene kan det være nyttig å utvikle teorier som kontekstualiserer det relasjonelle i samhandlingen.

\section{REFERANSER}

1. St.meld. 47. Samhandlingsreformen (2008-2009). Rett behandling - på rett sted - til rett tid. Helse- og omsorgsdepartementet. Oslo. 2009.

2. Melby L, Tjora A. Samhandlingens mange ansikter. I: Melby L. Tjora A. (red). Samhandling for helse. Kunnskap, kommunikasjons og teknologi i helsetjenesten. Gyldendal Akademisk. Oslo. 2013

3. Helles $\varnothing$ R, Fagermoen M-S. Cultural diversity between hospital and community nurses: implications for continuity of care. Journal of Integrated Care 2010;10;1-9.

4. Hellesø R, Melby L. Forhandlinger og samspill i utskrivningsplanleggingen av pasienter på sykehus. I. Melby L. Tjora A. (red). Samhandling for helse. Kunnskap, kommunikasjons og teknologi i helsetjenesten. Gyldendal Akademisk. Oslo. 2013.

5. Olsen RM. Informasjonsutveksling mellom sykepleiere i hjemmesykepleie og sykehus ved overføring av eldre pasienter. (Doktoravhandling). Kopieringen Mittuniversitetet, Sundsvall. 2013

6. Tingvoll WA, Sæterstrand T, Fredriksen ST. Kompetanse i tiltakskjeden-avdelingslederes erfaringer om utskrivninger av eldre pasienter fra sykehus. Vård i Norden 2010; 30:29-33.

7. Danielsen BV, Fjær S. Erfaringer med å overføre syke eldre pasienter fra sykehus til kommune. Sykepleien Forskning 2010; 5:1:28-34.

8. Groene RO, Orrego C, Sunol R, Barach P, Groene 0 . «ltss like two worlds apart»: an analysis of vulnerable patient handover practices at discharge from hospital. BMJ quality \& safety. 2012;21 Suppl 1:67-75

9. Debesay J, Harslof I, Rechel B, Vike H. Dispensing emotions: Norwegian community nurses s handling of diversity in a changing organizational con- text. Social science \& medicine. 2014 119:74-80.

10. Orvik A. Organisatorisk kompetanse. Innføring i profesjonskunnskap og klinisk ledelse. Cappelen Damm Akademisk. Oslo. 2014.

11. Helsedirektoratet. Samhandlingsavtaler mellom kommuner og helseforetak (10.02.2015). https:// helsedirektoratet.no/samhandlingsreformen/samarbeidsavtaler-mellomkommuner-og-helseforetak

12. Helse- og omsorgsdepartementet. Forskrift om kommunal betaling for utskrivningsklare pasienter 18.11.2011. 13. Helsedirektoratet. Samhandlingsstatistikk 2013-2014. (07.05.2015) http:// www. helsedirektoratet.no

14. Hermansen Å, Grødem AS. Redusert liggetid blant de eldste. Sykepleien Forskning 2015; 10:24-32.

15. Kassah BLL*, Tingvoll WA*, Dreyer Fredriksen ST. Samhandling-sykepleieledere og bestiller-utførerenhet. Geriatrisk sykepleie 2014; 3:26-33

16. Abelsen B, Gaski M, Nødland SI, Stephansen A. Samhandlingsreformens konsekvenser for det kommunale pleie- og omsorgstilbudet. IRIS Rapport 382/2014. (07.05.2015) http://www.iris. no/forskning/samfunn/politisk-organisering-og-styring/helse-og-omsorgsamhandlingsreformen

17. Grimsmo, A. Hvordan har kommunene løst utfordringene med utskrivningsklare pasienter? Sykepleien Forskning 2013; 8:148-155.

18. Norheim KH, Thoresen L. Sykepleiekompetanse i hjemmesykepleien-på rett sted til rett tid? Sykepleien Forskning 2015; 10:14-22.

19. Kassah BLL, Tingvoll W-A, Tønnessen S. Samhandlingsreformen-utfordringer, løsninger og implikasjoner. I Kassah, BLL, Tingvoll WA, Kassah AK (red). Samhandlingsreformen under lupen. Kvalitet, organisering og makt i helse- og omsorgstjenestene. Fagbokforlaget Vigmostad \& Bjørke AS. Bergen. 2014

20. Gautun H, Syse A. Samhandlingsreformen. Hvordan tar de kommunale helse- og omsorgstjenestene imot det $\emptyset k$ te antallet pasienter som skrives ut fra sykehusene? Rapport nr. 8/13. NOVA. 2013

21. Sæterstrand TM, Holm SG, Brinchmann BS. Hjemmesykepleiepraksis: Hvordan ny organisering av helsetjenesten påvirker sykepleiepraksis. Klinisk Sygepleje 2015:29:1:4-16.

22. Patton MQ. Qualitative research and evaluation methods. Sage Publications. Thousand Oaks. Calif. 2002.

23. Kvale, S. InterViews. An introduction to qualitative research interviewing. Sage pub. Inc. Thousand Oaks. Calif. 1997.

24. Hernes, G. Makt og avmakt. Universitetsforlaget. Oslo. 1975/1997.

25. Englestad, F. Hva er makt. Universitetsforlaget. Oslo. 2009

26. Kassah BLL, Jenssen GM, Tingvoll WA. Informasjonsflyt i omsorgstjenesten- bruk av elektronisk pasientjournal. I: Kassah, BLL, Tingvoll WA, Kassah AK (red). Samhandlingsreformen under lupen. Kvalitet, organisering og makt i helse- og omsorgstjenestene. Fagbokforlaget Vigmostad \& Bjørke AS. Bergen. 2014

27. Album D, Westin S. Do diseases have a prestisje hierarchy? A survey among physicians and medical students. Social science and medicine 2008:66:1: 182-188.

28. St.meld. 26. Fremtidens primærhelsetjeneste - nærhet og helhet (2014-2015). Helse- og omsorgsdepartementet. Oslo. 2015.

Les kommentaren på side 24 